\title{
Mapping Analysis of Conflict Potential Utilization of Coastal Area Desa Pangkung Tibah, Kediri, Tabanan
}

\author{
I Gde Putu Bayu Raka Purba ${ }^{1}$, I Gusti Ngurah Anom Rajendra ${ }^{2}$, and Ni Ketut Agusintadewi ${ }^{3}$ \\ Architectural Master's Program \\ Faculty of Engineering, Udayana University \\ Denpasar, Indonesia \\ rakapurba@gmail.com \\ Architectural Master's Program \\ Faculty of Engineering, Udayana University \\ Denpasar, Indonesia \\ Architectural Master's Program \\ Faculty of Engineering, Udayana University \\ Denpasar, Indonesia
}

\begin{abstract}
Pangkung Tibah Village is located in the southern coastal area of Bali Island. About 70 percent of the land area in this village has been ruled by investors for tourist accommodation, especially the area close to the beach. At the beginning, land acquisition plans were not well received by local villagers, but other approaches were made by investors, including involving security forces to force citizens to surrender their lands. Field data reveals various problems, such as land of citizens that are isolated without access in the land of investors, land use that is not proprietary, the potential destruction of the environment, actions that cause citizens to feel uncomfortable. This research aims to map the potential conflicts of coastal utilization of the village. The method used is a qualitative approach. Primary data collection is done by in-depth interviews with relevant informant and field observations. The results of the study identified land utilization perpetrators, potentially conflict locations, conflicting causes, conflict forms, level conflicts to date, and mapping potential conflicts of mild, moderate, and severe conflict levels. Potential conflict mapping analysis is based on territorial theory and conflict theory. Thus, the results of this research can be used as a basis for consideration by policy determinants (Government and indigenous leaders) to overcome the potential conflict of coastal utilization by coordinating the research results with Spatial planning and coastal area management strategies for sustainable economic, social and environmental development in research locations.
\end{abstract}

Index Terms - conflicts, coastal utilization, mapping, potential conflicts, coastal areas

\section{INTRODUCTION}

The development of development in the coastal areas of the island of Bali is growing rapidly. This development can be seen from the increasing number of coastal areas that are used for various uses. These uses range from traditional uses such as agriculture and fisheries, to modern uses, such as residential areas, industrial areas and tourist areas. The issues of utilization of coastal areas that occur on the island of Bali include reclamation that raises pros and cons, uncontrolled land use change, violations of coastal boundaries, violations of flora and fauna conservation areas, changes in the nature of public spaces to private, changes in sacred spaces to profane., violation of the radius of the sanctity of the temple, and others

Tabanan Regency as one of the nine regencies / cities in Bali Province has a coastline which is located in the southern coastal area of Bali Island. The coast of Tabanan Regency is used for various purposes, such as agriculture, fisheries, settlements, and tourism. The most prominent 
tourist attraction in the coastal area in Tabanan Regency is the Tanah Lot tourist attraction (DTW). This tourist attraction has an influence on the existence of the surrounding beaches. The construction of tourist accommodation around the area can be found on the coasts of Nyanyi, Kedungu, Pangkung Tibah, and Yeh Gangga Beach which have resulted in rapid land conversion.

The research was conducted in the coastal area of Pangkung Tibah Village, Kediri District, Tabanan Regency. Pangkung Tibah Village is one of 15 villages in Kediri District, located approximately $1.5 \mathrm{~km}$ to the west of Tanah Lot Beach. In accordance with the Regional Spatial Plan (RTRW) of Tabanan Regency for 2012-2032, Pangkung Tibah Village is included in the Tanah Lot Special Tourist Attraction Area (KDTWK). Based on observations, the utilization of the coastal area of Pangkung Tibah Village is designated as agricultural land, plantations, fisheries, settlements, tourism, mangrove conservation, as well as customary and religious activities.

Pangkung Tibah Village has an area of 199 hectares and about 70 percent of this area has been controlled by several investors which will be developed into the Ciputra Beach Resort, Purimas Strait Resort, and other tourist accommodation, especially, near the beach. Land acquisition for the development of tourist properties in the coastal area of Pangkung Tibah Village began in 1989. Initially, the land acquisition plan was not necessarily well received by the residents of Pangkung Tibah Village. Investors have taken various approaches, including involving elements of the apparatus to force residents to surrender their land.

In this land acquisition process, not all land owned by residents can be purchased by investors. Until now, there is land belonging to local residents that has not been released by the investor which is in the land owned by the investor. This land is isolated because it does not have clear access to the location. Interview with the Head of Pangkung Tibah, I Ketut Nandera, said that in carrying out their activities, indigenous peoples also feel uncomfortable with the presence of tourism accommodation development on the coast. The locations of customary and religious activities are often scattered alongside the land owned by investors. The indigenous people feel that their space is limited. Every time they carry out activities, they must coordinate in advance with the investor, even though access to the beach is public property. This limitation in activities is unprecedented.

This paper aims to map potential conflicts over the use of coastal areas in the village of Pangkung Tibah, Kediri, Tabanan. The initial stage in coastal area management is to identify land use, including actors and their interests, and conflict as a basis for consideration for coastal spatial planning. The identification and mapping of potential conflicts is carried out on various uses in coastal areas that intersect or are close to each other, both those that have the potential to not support each other or those that support each other. Collaborating on conflict mapping in the coastal area spatial planning process is a step towards reaching a mutual agreement to achieve development goals, namely environmental, social and economic harmony.

\section{REVIEW OF LITERATURE}

\section{A. Mapping of Potential Conflict in Coastal Zone Utilization}

Every community group has a number of potential conflicts because every citizen has interests that must be met. In fulfilling these interests, sometimes ignoring the interests of other residents. If it is done without following legal rules, customary law, custom, or applicable social conventions, it can be a potential conflict [1]. Thus, the potential for conflict in the use of coastal areas can be said to be a difference or conflict of interests and views in terms of utilization of space and resources of coastal areas by users of these resources which are hidden and can become a bigger thing.

The amount of resources in the coastal area can cause various problems. The unified use of coastal space can lead to conflicts of interest between various sectors [2]. The coastal and marine spatial planning approach with a territorial approach is very important for the sustainability of natural resource management, because at that level there is a very complex combination of ecological, social and economic phenomena between the two regions [3] .

Prestelo and Vianna [3] state that coastal spatial planning is very important to solve spatial use conflicts, namely by identifying and mapping all uses, regulations, and conflicts that occur. According to Brown and Christopher [3], at first the conflict occurred in the ecological aspect, then led to social conflict and finally economic conflict. Meanwhile, Diposaptono [3] conveyed that conflict identification and mapping was carried out on various activities (zones) in coastal areas that intersect or are close to each other, either potentially incompatible or compatible between the two.

The coastal area which consists of land (terrestrial) and water areas has very dynamic characteristics. Between terrestrial areas and waters influence each other both ecologically and socially [3]. Prestelo and Vianna, in Mujio et al [3] state that coastal spatial planning is very important to solve spatial use conflicts, namely by identifying and mapping all uses, regulations and conflicts that occur.

The planning process can identify and assist conflicts that occur in coastal areas, the interaction of human activities, and the cumulative impacts of these activities, especially conflicts between several area users. Incorporating the conflict identification process in the spatial planning process of coastal areas is a step to reach mutual agreement to achieve ecological and socio-economic goals [3].

It can be concluded that the mapping of potential conflicts is an analysis that explains the relationship 
between conformity and contradictory relationships between adjacent activities in an area by considering social, economic and environmental aspects. In the potential conflict phase, conflicts have occurred, but at a very low level of intensity. Structural factors and causes of conflict lead to differences between groups, as well as socioeconomic, cultural and political differences. In this phase there are many problems, they are hidden, and need to be raised to the surface so that they can be handled. Community life that appears stable and harmonious is not a guarantee that in society there is no hostility and conflict. Preventive action in this phase is not risky and has the potential to succeed [3].

The theories used as the basis for analysis in this paper are territory theory and conflict theory. Territoriality according to Edney in [4] is something related to physical space, signs, ownership, defense, exclusive use, personalization and identity. Territoriality can also affect the behavior of a person or group of people because territoriality is closely related to control, conflict, security, lawsuits and defense.

Robbin in [5] states conflict is a process that starts when a party feels that another party is giving it a negative influence or when one party feels that their interests have a negative influence on the other party. The form of conflict covers a very wide range, from vague disagreements to acts of violence. Every difference is a potential conflict, which if not handled properly, the potential conflict can turn into open conflict.

\section{RESEARCH METHOD}

This research uses a qualitative approach. The qualitative approach emphasizes research procedures that produce descriptive data, in the form of speech or writing and the behavior of the people being observed. The qualitative approach to this research uses an inductive mindset (specifically to the general) because it starts from existing data / phenomena, not from a theory.

Primary data were obtained from informants / informants by conducting unstructured interviews and guided by interview guidelines. Resource persons are a number of parties who have the competence to provide information relevant to the research theme, including sources who know the area of Pangkung Tibah Village clearly and people who are responsible for services and customs in Pangkung Tibah Village, such as Pangkung Tibah Village Headquarters, Jro Bendesa Adat Bedha, Kelihan Banjar Adat, Kelihan Banjar Dinas. In addition, interviews were also conducted with investors and villagers. Field observations were carried out to obtain data in the form of a description of the utilization of coastal areas that could potentially conflict.

Secondary data sources in the research in the form of reference studies, literature and standard regulations were obtained including from the Pangkung Tibah Village Office, Tabanan Bappeda Office, Tabanan Regency Agriculture and Food Crops Office, Tabanan Regency Central Statistics Agency and searches through websites on the internet and literature on utilization conflicts. the coast.

Field data in the form of interviews and recordings are converted into written form, simplified by grouping, and presented with tables, graphs, or pictures. Data in the form of images (photos, sketches, maps) are also interpreted in the form of thematic maps to facilitate data analysis. Data presentation is made in the form of a brief description or descriptive of the relationship between categories, namely the relationship between the use of coastal areas and the potential for conflicts that can arise. The theoretical approach, namely the theory of territory and conflict, is used as a reference in analyzing research cases. At the end of the analysis a conclusion is drawn that summarizes the contents of the discussion.

The administrative area of Pangkung Tibah Village with an area of approximately 199 hectares, consists of three official banjars and five traditional banjars. This village is directly adjacent to Bengkel Village to the north, Yeh Bumbung River / Belalang Village to the east, Samudera Indonesia to the south and Yeh Empas River / Sudimara Village to the west. (see Figure 1) 


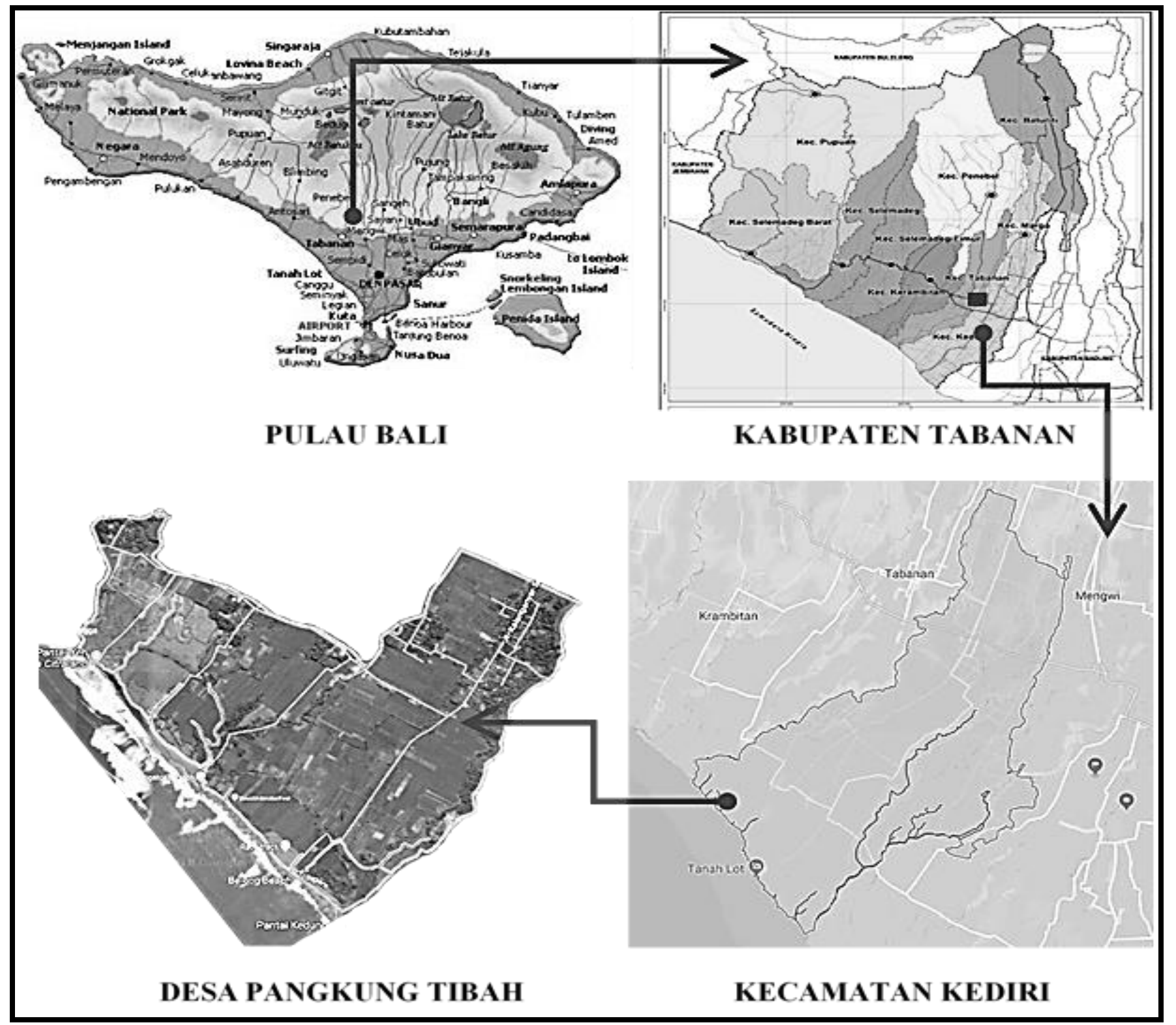

Fig. 1. Administration of Research Areas and Research Sites.

Soursce: https://www.google.co.id

\section{RESUlT AND DISCUSSION}

\section{A. Coastal Area Utilization Actors}

The actors in the utilization of the coastal area of Pangkung Tibah Village who are classified into the policymaking level are the local government, village government, and leaders of customary institutions. These actors have the role of formulating and determining local policies and regulations in the form of awig-awig and perarem. Meanwhile, other actors involved are actors at the operational level, namely village communities who work as farmers or cultivators, residents of neighboring villages, fishermen, and tourism actors / investors. (see Table 1) 
TABLE 1

COASTAL AREA UtILIZATION ACTORS, THEIR INTERESTS AND LEVELS

\begin{tabular}{|c|c|c|c|}
\hline Civitas & Interest & Level & Object \\
\hline $\begin{array}{l}\text { Village communities who work as } \\
\text { farmers and tenant farmers }\end{array}$ & $\begin{array}{l}\text { Has an interest in utilizing the coastal area for agricultural activities } \\
\text { where it collides with tourist accommodation activities that will be built } \\
\text { later }\end{array}$ & Operasional & $\begin{array}{l}\text { Village communities } \\
\text { who work as farmers } \\
\text { and tenant farmers }\end{array}$ \\
\hline Farmers whose land is isolated & $\begin{array}{l}\text { Want access to their isolated land. If this is not possible, investors are } \\
\text { expected to be willing to buy their land at a fair price } \\
\text { Operasional }\end{array}$ & & $\begin{array}{l}\text { Farmers whose land is } \\
\text { isolated }\end{array}$ \\
\hline Villagers & Has an interest in using the land on the beach for religious rituals & Operasional & Villagers \\
\hline Fisherman & Has an interest in utilizing coastal waters for fisheries activities. & Operasional & Fisherman \\
\hline Tourism actors / investors. & $\begin{array}{l}\text { Utilizing the coastal area as a location for tourist accommodation, elite } \\
\text { housing and other tourism support facilities }\end{array}$ & Operasional & $\begin{array}{l}\text { Tourism actors / } \\
\text { investors. }\end{array}$ \\
\hline Customary institutions & $\begin{array}{l}\text { Wishes for harmony in economic development and customs, culture, as } \\
\text { well as maintaining the existence of existing ancestral heritage. }\end{array}$ & Goverment & Customary institutions \\
\hline Village government & $\begin{array}{l}\text { Want the welfare of rural communities, especially safety and comfort in } \\
\text { carrying out economic activities and preserving the coastal } \\
\text { environment. }\end{array}$ & Goverment & Village government \\
\hline Regional government & $\begin{array}{l}\text { Wanting general public welfare, safety and comfort in carrying out } \\
\text { economic activities and preserving the coastal environment. }\end{array}$ & & Goverment \\
\hline
\end{tabular}

\section{B. Locations of Potential Conflict}

Location 1. Isolated Residents 'Land in Investors' Land

Interview data obtained data on a number of rice fields and moorland residents who are isolated in the investor's land, which are spread over four subak areas. The land that has not been acquired is 14 hectares from the planned land acquisition zone of 154 hectares.

Kriesberg, (1998) states that conflict arises when two or more people or groups show that they have different views. This happened to two groups that had different views, namely villagers and investors. The villagers thought that their isolated land was causing inconvenience, so they decided to sell their land to investors which they considered the most suitable solution. However, investors do not consider the isolation of residents 'land within the investor's land, and it is not an obligation for investors to solve this problem of isolation by buying the residents' land.

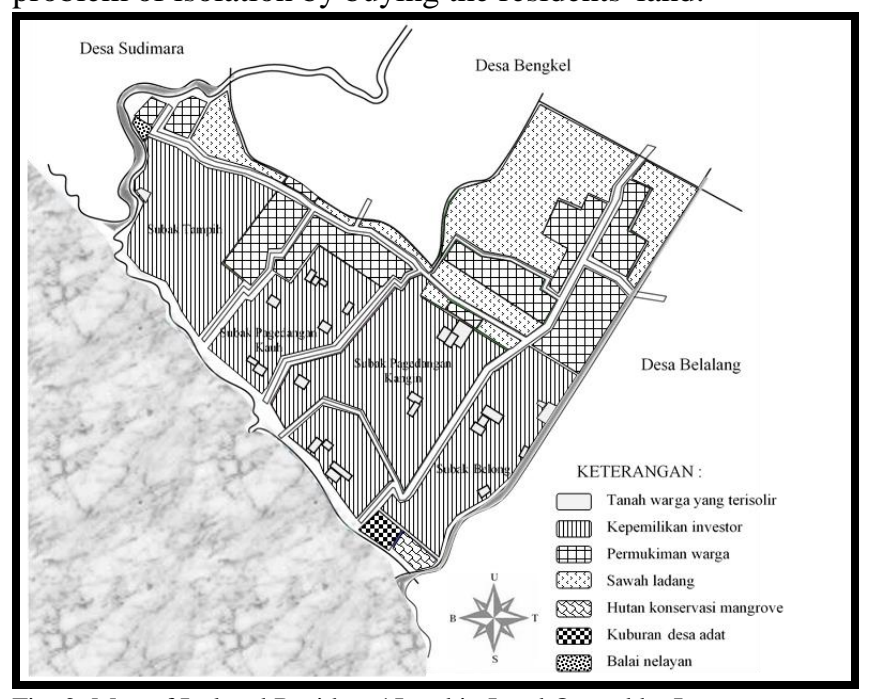

Fig. 2. Map of Isolated Residents' Land in Land Owned by Investors

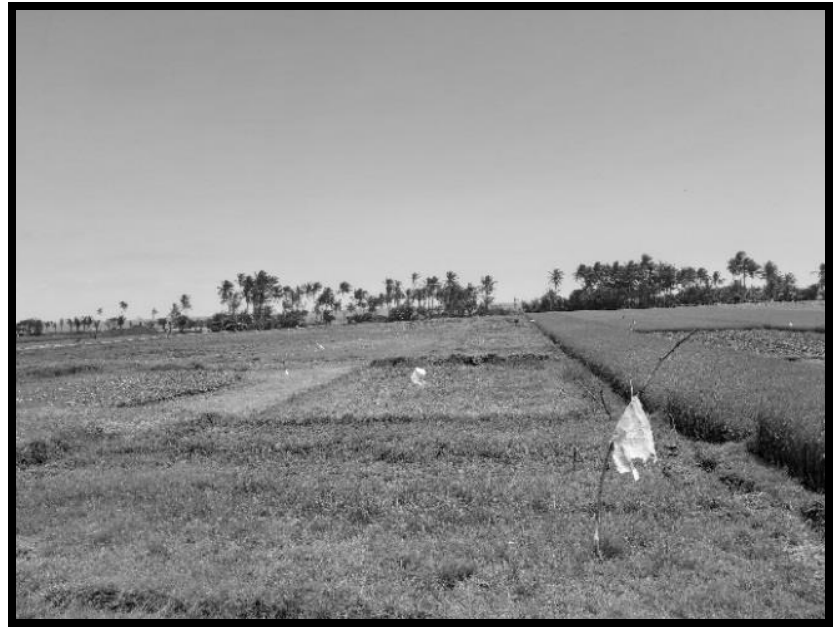

Fig. 3. Isolated residents 'land which is still planted with rice is in the investors' land that is left to dry.

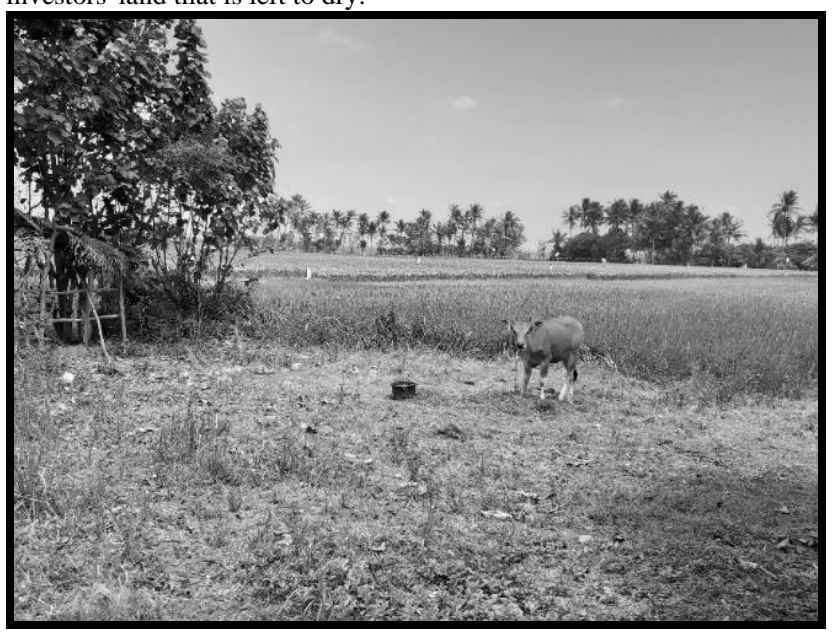

Fig. 4. Isolated land belonging to residents is used to raise livestock

Location 2. Area of Mangrove Conservation Forest, Traditional Village graves and Investor's land

A second location with a potential for conflict has several different interests that overlap. At this location there are three different uses, namely the mangrove forest area (owned by the Tabanan Regency Government), state land 
used as a cemetery for customary villages and land owned by investors. These three different uses of the area bring potential conflicting interests. An illustration of the side by side use that has the potential for conflict can be seen in Figure 5.

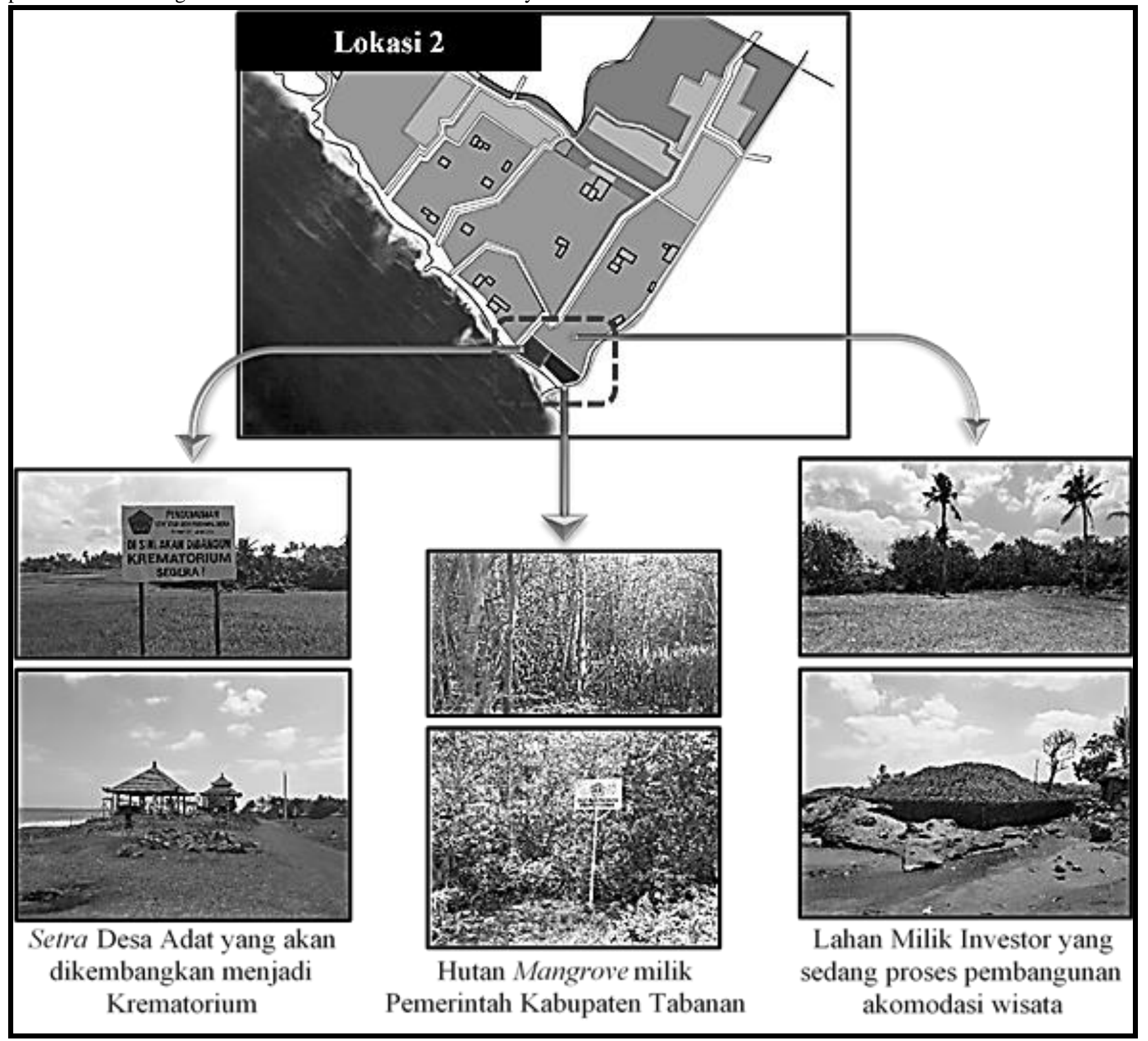

Fig. 5 Utilization that has the potential for conflict in the location 2

At Location 2, there are several potential land uses for conflict. The use of the grave area of the customary village by other customary village residents without permission, the threat of the district government's mangrove forest by development on the part of the investor, and the land owned by the investor which is used for parking by the customary village without the permission of the investor. These land uses influence each other (see Figure 6 and Figure 7).

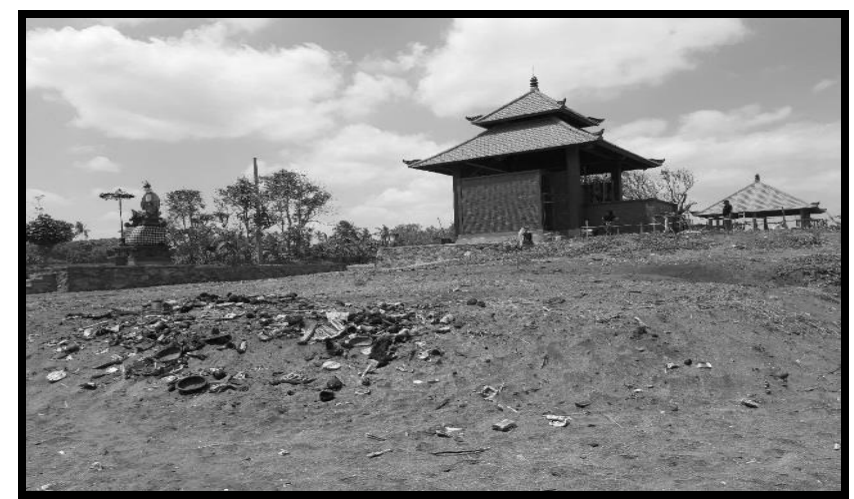

Fig. 6 Traditional Village Grave Area with Potential Conflict at Location 2 


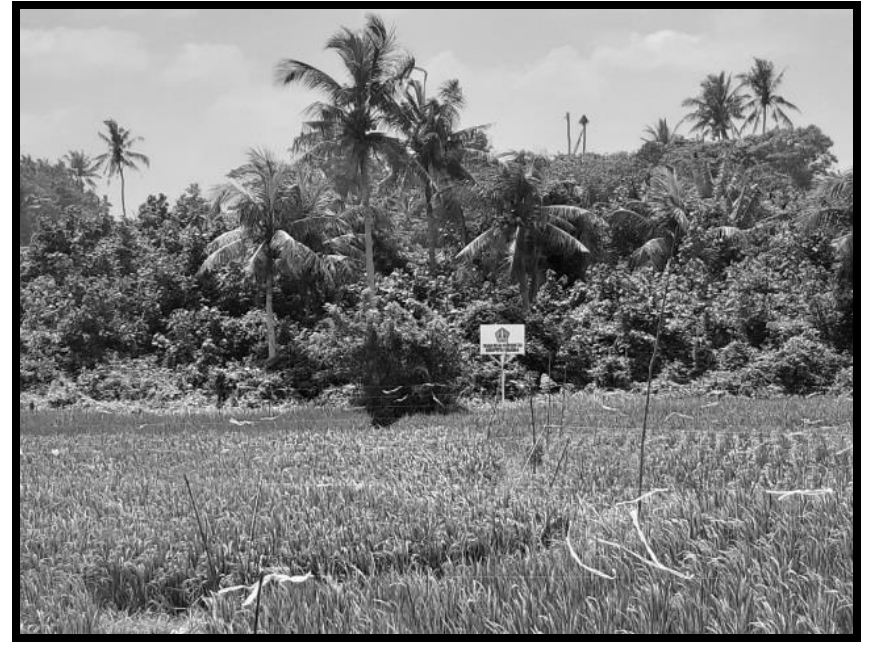

Fig. 7. Mangrove Forest Owned by District Government at Location 2

Location 3. Banjar Tampih Kanginan Cemetery and Villa Investor

The next potential location for conflict is in Banjar Tampih Kanginan, Pangkung Tibah Village, hereinafter referred to as Location 3. At this location there are two uses side by side, namely the Banjar Adat Tampih Kanginan cemetery and the investor's villa in Banjar Tampih Kanginan. This investor's villa is located between Pura Dalem and a cemetery. (see Figure 9)

Before there were villas, the villagers were free to use the road as access to the cemetery. After that, there are things that villagers need to do before carrying out a religious ritual procession by informing the villa manager (see Figure 8). Villagers feel depressed, this is in accordance with Anggun's (2012) statement, namely the potential for conflict in a person or group of people is indicated by feelings of pressure due to the actions of the opposing party.

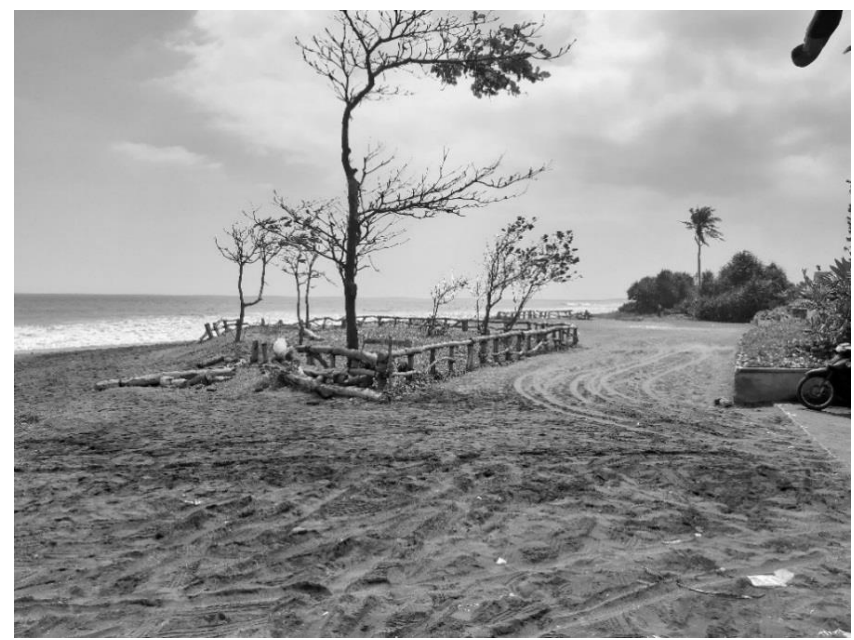

Fig. 8. Access in Front of the Villa Towards the Tampih Kanginan Cemetery

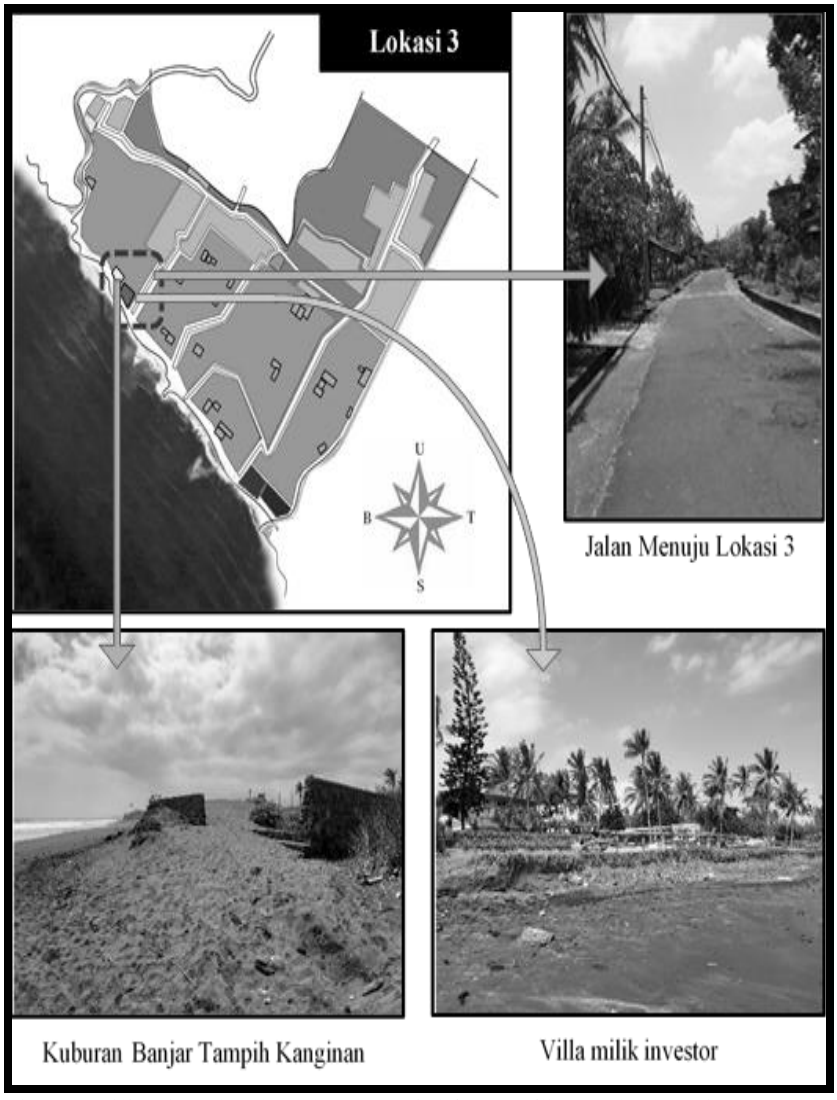

Fig. 9. Utilization that has the potential for conflict at the location 3

\section{Potential Causes of Conflict}

The causes of potential conflicts in the use of coastal areas in the research location were identified to map the potential for further conflicts. In accordance with Dorcey's opinion [6], the basic causes of conflict are: 1) differences in knowledge or understanding; 2) difference in value; 3) differences in interests; 4) personal problems or because of historical background. The results of the analysis show that the three locations with the potential for conflict have four factors that cause conflict.

\section{Potential Forms of Conflict}

Conflict can take the form of closed (latent) and open (manifest) conflicts. Closed conflict is characterized by the presence of pressures that are not visible and are not fully developed and have not been lifted to the surface. Open conflict (manifest) is a dispute in which the parties involved can be identified and actively involved in the dispute that occurs [7]. 
TABLE 2

POTENTIAL FORMS OF CONFLICT IN THE USE OF COASTAL AREAS

\begin{tabular}{|c|c|c|c|}
\hline Location & Konflict & $\begin{array}{l}\text { Form of } \\
\text { Conflict }\end{array}$ & Location \\
\hline Location 1 & $\begin{array}{l}\text { Farmers whose land is isolated plan to raise pigs or ducks so that the smell will disturb tourist accommodation in } \\
\text { the vicinity. Thus the problem can get immediate attention. This action was limited to the intention of the farmer. }\end{array}$ & & Location 1 \\
\hline & Closed & & \\
\hline \multirow[t]{2}{*}{ Location 2} & $\begin{array}{l}\text { The residents feel disturbed by the activities of neighboring villagers who use their territory to carry out cremation / } \\
\text { ngaben ceremonies without permission. The annoyance hasn't developed into something concrete like a dispute. }\end{array}$ & & Location 2 \\
\hline & Closed & & \\
\hline Location 2 & $\begin{array}{l}\text { Customary village use of parking land which actually belongs to the investor. The unauthorized use of parking lots } \\
\text { has the potential to cause conflict, but currently it has not yet surfaced. }\end{array}$ & & Location 2 \\
\hline & Closed & & \\
\hline Location 3 & $\begin{array}{l}\text { The feeling of the residents was disturbed by the request of the villa manager to coordinate and announce the } \\
\text { customary activities that would be carried out by the residents. However, the residents did not express this feeling } \\
\text { clearly. }\end{array}$ & Tertutup & Location 3 \\
\hline
\end{tabular}

So it can be concluded that the form of potential conflict in the use of coastal areas in the research location is in the form of latent (closed) conflict. This conflict is not yet clearly visible on the surface. The parties that have conflicting interests have not created clear disputes.

\section{E. Stages of Conflict}

The conflict stage has been latent (closed). Associated with the stages of conflict development by Mochran (2003), namely (1) Stage 1: Latent Conflict; (2) Stage 2: Conflict Begins to Emerge; (3) Stage 3: Conflict without Violence; (4) Stage 4: Violent Conflict

Judging from the stages of conflict development, it can be concluded that the conflict over the use of coastal areas in the research location is still at Stage 1, namely the latent conflict stage. At this stage, conflicts between parties with different interests have not yet surfaced. The dispute has not yet appeared. However, if this potential conflict is handled immediately, the success rate is quite large and does not cause big losses either.

\section{F. Potential Conflict Mapping Analysis}

Relationships have the potential for minor conflict if one of the three aspects of sustainable development (social, economic and environmental) is disrupted. Potential conflict is occurring when two aspects of the three aspects are disturbed, while the potential for serious conflict is identified if all three aspects of sustainable development experience problems.

The interaction of actors and interests at Location 1 has the potential for moderate conflict because it involves problems in only two aspects, namely social and economic aspects. Disturbed social aspects are reflected in the conflicting views, understandings and values of the actors. The disruption of the economic aspect can be seen in the different views of the actors regarding the valuation of isolated land.

Location 2 found the potential for serious conflict because there are three problems in environmental, social and economic aspects among actors who have an interest in that location. The disturbed social aspect can be seen in the different views of the actors regarding their interests in utilizing the coastal areas in this location. For the economic aspect that is disturbed, it can be identified in the use of land owned by other parties, without being accompanied by an economic contribution, meanwhile, the environmental aspect that is disturbed is the mangrove forest surrounded by development and other potentially detrimental uses.

In location 3, it was found the potential for minor conflict between the villa owner and the indigenous community because they only had problems in the social aspect that was disturbed, namely the annoyance of the indigenous people towards the request of the villa owner. Mapping potential conflicts can be seen in Figure 10.

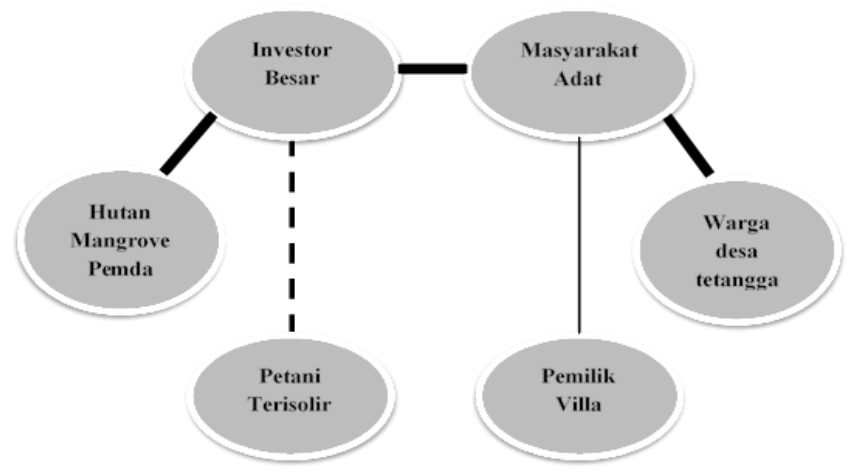

Fig. 10. Conflict Mapping Diagram

\section{CONCLUSION}

Based on the results of the research, it can be concluded that the actors of the utilization of the coastal area of Pangkung Tibah Village are divided into two, namely policy-determining actors and operational actors who carry out their own roles without a coordination forum. In the research location, it was found three locations that have the potential for conflict in this village with various conflicting interests in them. The causes of potential conflicts at the research location are differences in knowledge or 
understanding, differences in values, differences in interests and personal problems or because of historical backgrounds. This conflict is not yet clearly visible on the surface. The conflicting parties have not created clear disputes so that they are in the form of a latent (closed) conflict.

The mapping analysis of potential conflicts found three levels of potential conflict in the utilization of coastal areas, namely the potential for minor conflict with disruption of social aspects, potential for moderate conflict with disruption of social and economic aspects and potential for serious conflicts with disruption of social, economic and environmental aspects. The results of this mapping analysis by policy-making actors (government and traditional community leaders) can be used as a basis for collaboration with planning and management of the utilization of the coastal area of Pangkung Tibah Village.

\section{REFERENCES}

[1] Anggun., "Konflik dan Potensi Konflik", Retrieved 7 Maret, 2018, from https://goenable.wordpress.com/tag/potensi-konflik/., 2012.

[2] Ali, M., "Pemanfaatan Ruang Kawasan Pesisir sebuah "Keniscayaan"”, Prosiding Temu Ilmiah Ikatan Peneliti Lingkungan Binaan Indonesia di Universitas Sam Ratulangi. 2015.

[3] Mujio, L.A., Soewardi, K, Wardiatno Y., "Analisis Potensi Konflik Pemanfaatan Ruang Kawasan Pesisir : Integrasi Rencana Tata Ruang Darat dan Perairan Pesisir”, Jurnal Sosiologi Pedesaan, Vol 4, No 2, 2016.

[4] Marcella, J., "Arsitektur \& Perilaku Manusia”, Grasindo, 2004.

[5] Darwin, M., \& Sugiana, I. K., "Konflik pemanfaatan sumberdaya pesisir pulau-pulau kecil di Kecamatan Siantan dan Palmatak Kabupaten Natuna", Universitas Gadjah Mada, 2005.

[6] Mitchell, C. R., "The structure of international conflict", Springer, 1989.

[7] Fuad, F. H., \& Maskanah, S., "Inovasi penyelesaian sengketa pengelolaan sumber daya hutan", Lembaga Alam Tropika Indonesia, 2000 . 